S2-09

チトクロームP-450 3Aの阻害による薬物相互作用の予測

: in vitro から in vivo 、動物からヒトへ

エーザイ筑波研究所 ○楠部健一、中村俊弘、鈴木弘眞、

谷口朋義、中井 弘、伊藤初江、堀江 透

アマシャム開発研 田井中 均、筒井通夫

\title{
PREDICTION OF DRUG-DRUG INTERACTION CAUSED BY CYP3A INHIBITION: FROM IN VITRO TO IN VIVO, FROM ANIMAL TO HUMAN.
}

Kenichi Kusube, Tosihiro Nakamura, Hiromasa Suzuki, Tomoyosi Taniguchi, Hiromu Nakai, Hatue Ito, Toru Horie 1) Hitoshi Tainaka, Michio Tsutsui 2)

1) Tukuba Research Laboratories, Eisai Co.,Lyd.

2) Central Laboratory, Amersham K.K

【目的】E4080は心拍数を軽度に下げ るとともに、冠血流量増加作用を有 する狭心症治療薬をめざした化合物 である ${ }^{1,2)}$ 。化学構造はイミダゾール

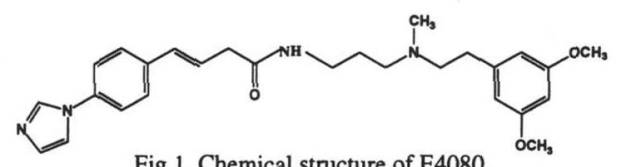

Fig.1. Chemical structure of E4080. 基を有するホモベラトリルアミン誘導体であり、このイミダゾール基が 経口有効性に必須である。イミダゾール基を有することからチトクロー 厶P450 への影響が懸念され、薬物相互作用の面から詳細な検討が要求さ れる。

【方法】In vitro study

基質結合差スペクトル ラット、ビーグル、アカゲザルおよびヒト肝ミクロソームに E4080を添加してP450とE4080の基質結合差スペクトルを紫外可視分光光度計を用いて 測定し、393 nm と $429 \mathrm{~nm}$ の吸光度差を解析した。

antipyrine代謝分子種の検討 1) ワクシニアウイルスによって10種のヒトP450を発現さ せたHepG2cellを用いて antipyrineの代謝を行い、代謝物をHPLCにより測定した。2）10 種の個体別ヒト肝ミクロソームを用いて antipyrineの代謝物をHPLCにて測定した。各代 謝物の生成量と個体別肝ミクロソームの標準基質における各分子種の活性との相関を検 討した。

ラット肝ミクロソームを用いたE4080の阻害分子種の検討 Testosterone代謝物7 $\alpha 、 6$ $\beta 、 16 \alpha 、 16 \beta$ および $2 \alpha$ 水酸化体の生成をHPLCにて測定した。

ヒト肝ミクロソームを用いたE4080の阻害分子種の検討 7 種の特異的なP450分子種で 代謝される標準基質の代謝に対するE4080の影響を検討した。

cortiol代謝分子種およびE4080影響の検討 ワクシニアウイルスによって10種のヒト P450を発現させたHepG2cellを用い、cortisol代謝物である6 $\beta$-hydroxycortisol(6 $\beta$-OHF)を 
HPLCにて測定した。また、ヒト肝ミクロソームを用いて、cortisol代謝に及ぼす $3 A$ 抗体 の影響を検討した。同様にE4080がcortisolの6 $\beta$ 水酸化に及ぼす影響について検討した。

In vivo study

薬効血中濃度相関 麻酔および無麻酔犬にE4080を定速静注し、冠血流量（CBF）、心 拍数（HR）および血圧（mAoP）をモニターするとともに血漿中未変化体濃度をHPLC により測定し有効血槳中未変化体濃度を推定した。

各種動物E4080 pharmacokinetics ラット、ビーグルおよびアカゲザルにE4080を静脈内 投与および経口投与しファーマコキネティックパラメータを求めた。

各種動物antipyrine clearance test ラット、ビーグル、およびアカゲザルにE4080を経 口投与し、投与後30分時にantipyrineを静脈内投与し血漿中antipyrine濃度をHPLCにより 測定した。

\section{Clinical study}

ヒト臨床第一相試験における血中濃度推移および尿中 $6 \beta-O H F の$ 測定 ヒト臨床第一相 試験におけるE4080 10、30、100 mg/man投与時の血漿中未変化体濃度をHPLCにより測 定した。また、尿中の6 $\beta$-OHFをHPLCにより測定した。

\section{【結果・考察】}

〈薬効血中濃度相関〉 E4080の血槳中未変化体濃度と薬理作用（冠血流 量、心拍数、血圧) は麻酔犬、無麻酔犬ともに良好な相関が認められ推 定最少有効血漿中未変化体濃度は $1 \sim 2 \mu \mathrm{g} / \mathrm{ml}$ と推定された。ラット、ビ ーグルおよびアカゲザルに経口投与した際のpharmacokineticsを検討した

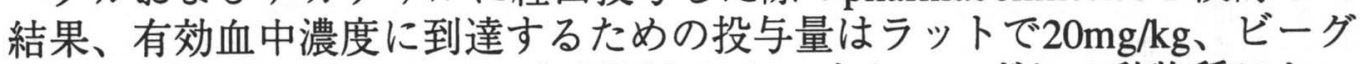
ル、アカゲザルでは $10 \mathrm{mg} / \mathrm{kg}$ と判断された。また、いずれの動物種におい ても薬効用量範囲で投与量とCmax、AUCとの間に非線形性が認められ た。

〈p450基質結合差スペクトル〉 各種動物の肝ミクロソームを用いて $\mathrm{E} 4080$ と肝チトクロームP450の親和性を調べた。P450へムとイミダゾー ル基の結合 ${ }^{3}$ に基づくと思われる極大 $432 \mathrm{~nm}$ 極小393nm のType II スペクト ルがラット、ビーグル、アカゲザルおよびヒト肝ミクロソームにおいて 認められ、E4080と肝チトクロームP450との強い親和性が示唆された。

〈アンチピリンクリアランステスト〉 肝薬物代謝酵素阻害作用をin vivoで確かめるため antipyrine) 出用いてクリアランステストを行った。推 定薬効量においてラット、ビーグルおよびアカゲザルいずれの動物種に おいても antipyrineの半減期の延長、クリアランスの低下が認められin vivoにおいてE4080のP450 阻害作用が認められた。

〈アンチピリンのヒト代謝P450分子種の特定〉 E4080のantipyrine代謝阻 害に関与する分子種を検討するためヒトP450発現系" ${ }^{5}$ を用いてin vitroにお けるantipyrine代謝を検討した。antipyrineの 3 種の代謝物 4 hydroxyantipyrine(OHA)、3-hydroxy-methylantipyrine(HMA)、 
norantipyrine(NORA)はそれぞれOHAはCYP1A2および3A4、HMAは CYP1A2および2C9、NORAは2C9で主に生成することが確認された。ま た、10種の個体別ヒト肝ミクロソームによるそれぞれの代謝物の生成量 と標準基質活性との間にも先の分子種との相関傾向が認められた。この 結果から antipyrineは複数種の肝チトクロームP450によって代謝されるこ とが裏付けられ、特にヒトにおけるmajorなP450分子種6) (3A,2C) を反映 することから antipyrineクリアランス薬物代謝酵素阻害試験の妥当性が検 証できた。

〈ラットおよびヒトにおけるE4080の阻害分子種〉 ラット肝ミクロソー ムを用いたtestosterone代謝”に及ぼすE4080の影響についてを検討した。 $\mathrm{E} 4080$ は $6 \beta$ および16 $\beta$ の水酸化を強く阻害したことからラットにおいて CYP2Bおよび3Aを阻害することが確認された。さらにヒト肝ミクロソー ムを用いて阻害分子種を検討した。E4080は7-benzyloxy-resolfin(IC50 $5 \mu$ M)、 tolbutamide (IC50 $2 \mu \mathrm{M}$ )、 bufuralol(IC50 $0.5 \mu \mathrm{M}$ )、 testosterone (IC50 $2 \mu \mathrm{M})$ の代謝を阻害し7-ethoxyresolfin、coumarin、anilineの代謝には影響 を与えなかった。従ってE4080はヒトにおいてCYP2B6、2C9、2D6、3A4 を㗁害するが、CYP1A2, 2A6, 2E1 には影響を与えないことが示された。

〈in vitro コルチゾール代謝〉 ヒトin vivoにおける非侵襲的な薬物代謝 酵素の阻害および誘導マーカーとして尿中の $6 \beta-O H F の$ 測定はP4503Aへ の影響を反映することが報告されている ${ }^{8)}$ 。これをin vitroで確かめるため の検討を行った。ヒト発現系を用いcortisolの代謝を行った結果、代謝物 である6 $\beta-O H F は$ 主にCYP3A4によって生成することが確認され、またヒ 卜肝ミクロソーム代謝においてCYP3A抗体によりこの生成が抑えられた ことから cortisolから $6 \beta-\mathrm{OHF}$ の代謝はCYP3Aが関与していることが裏 付けられた。さらにE4080はヒト肝ミクロソームによるcortisolから6 $\beta$ OHFへの代謝を阻害した $(\mathrm{Ki}=$ 約 $7 \mu \mathrm{M})$ ことからヒトphaseI臨床試験におい て尿中の6 $\beta$-OHFの測定を試みた。

〈phase I 臨床試験〉 ヒト臨床試験第一相においてE4080 $100 \mathrm{mg} / \mathrm{man}$ 投 与時の血漿中未変化体濃度は5例の平均でTmax $0.73 \mathrm{hr} 、 \mathrm{Cmax} 472.2 \mathrm{ng} / \mathrm{ml}$ 、AUC $747.5 \mathrm{ng} \cdot \mathrm{hr} / \mathrm{ml}$ とビーグル、アカゲザルにおける $3 \mathrm{mg} / \mathrm{kg}$ 投与時 の血漿中未変化体濃度推移に近似していた。しかし、個体別には大きな バラッキが認められ、尿中に排泄された $6 \beta-O H F の$ 量にも個体差が認め られた。E4080投与後6時間までに排泄された6 $\beta$-OHF量とAUCと間には AUCが大きな個体ほど尿中に排泄された $6 \beta-O H F の$ 量が少ないという相 関傾向が認められた。従ってE4080は臨床においてもCYP3Aを阻害する 可能性が強く示唆された。CYP3Aは臨床における薬物相互作用に最も 
留意すべき分子種であり、E4080の臨床効果を確認するために増量するこ とは臨床上、問題が生ずる可能性が予測された。

【結論】薬物相互作用をin vitro からin vivo、動物からヒトへ予測するこ とはこれからの新薬開発には重要な課題であり、今後も知見を積み重ね 創薬の初期段階にこれらの手法を生かし意志決定していくことが重要で ある。

【ABSTRACT】 Inhibitory effect of E4080 on the cytochrome P450 was studied using laboratory animals in vitro and in vivo.

In vitro study $\mathrm{E} 4080$ has a high affinity for $\mathrm{P} 450$ heme in rat, dog, monkey and human liver microsomes. In rat microsomes, E4080 inhibited testosterone $6 \beta$ and $16 \beta$ - hydroxylase which are involved in CYP2B and CYP3A. Using human microsomes, E4080 inhibited metabolism of 7-benzyloxyresolfin, tolbutamide, bufuralol and testosterone. These results suggest that E4080 inhibits CYP 2B6, 2C9, 2D6 and 3A4 in human liver microsomes.

In vivo study E4080 prolonged antipyrine half-life and decreased antipyrine clearance in rats, dogs and monkeys at the doses of $10 \mathrm{mg} / \mathrm{kg}$ which exert pharmacological effect postulated from the minimal effective plasma concentrations $(1-2 \mu \mathrm{g} / \mathrm{ml})$. The results may be suggested that E4080 interacts with antipyrine metabolism which is thought to be carried out by CYP $1 \mathrm{~A}, 2 \mathrm{C}$ and $3 \mathrm{~A}$.

In the clinical trial $\mathrm{E} 4080(100 \mathrm{mg} / \mathrm{man})$ decreased the excretion of urinary $6 \beta$ hydroxycortisol which is a marker of human hepatic cytochrome P4503A induction and inhibition.

In conclusion, it is suspected that E4080 inhibits CYP3A not only in animals, but also in human and should be noticed drug-drug interaction in clinical use.

\section{【REFERENCES】}

1) Kawamura et al., Eur. J. Pharm., 203 399-404 (1991).

2) Adachi et al., Eur. J. Pharm., 268 1-6 (1993).

3) Murray et al., Drug Metabolism, Reviews., 18 55-81 (1987).

4) Vessel et al., Clin. Pharmacol. Ther., 26 275-286 (1979).

5) "Methods in Enzymology" , 206 85-92 Academic Press INC.(1991)

6) Shimada et al., J.Pharm. Exper. Ther., 270 414-423 (1979).

7) "Methods in Enzymology" , 206458 Academic Press INC.(1991)

8) Ged et al., Br. J. Clin. Pharmac., $\underline{28}$ 373-387 (1989). 